\author{
ISSN: 2146-3042
}

DOI: $10.25095 /$ mufad.673675

\title{
İmalat Sanayi ve Finansal Sektörde Temettü Dağıtımlarının Kısa Dönemli Fiyat Etkisi: BİST Uygulaması*
}

\author{
H. Aydın OKUYAN** Şakir SAKARYA** Celil AYDIN $^{* * * *} \quad$ Devran DENIZ*****
}

\section{ÖZET}

Bu çalışmada Borsa İstanbul'a kayttl imalat sanayi ve finansal sektör şirketlerinde pay sahiplerine yapılan nakit temettü dağgtımlarının pay senedi üzerinde kısa dönemli fiyat etkisi yaratıp yaratmadığ $2006-2018$ verileri ile olay etüdü yöntemi kullanılarak araştırılmıştır. Bu amaçla söz konusu dönemde gerçekleştirilen 1.307 adet temettü duyurusu için 3 günlük olay penceresinde normalüstü getiriler analiz edilmiştir. Bir önceki yıla göre temettü artıs duyurularında pozitif, azalış duyurularında negatif normalüstü getiriler görülmüștür. Benzer şekilde yüksek temettü verimine sahip duyurularda pozitif, düşük temettü verimine sahip duyurlarda negatif normalüstü getiriler elde edilmiștir. Ayrica yapllan panel regresyon analizi sonucunda, olay penceresindeki normalüstü getiri ile temettü verimi/temettü değișimi değișkenleri arasında pozitif yönlü doğrusal ilişki tespit edilmiştir. Bu ilişki imalat sanayi sektöründe büyük ve küçük ölçekli tüm șirketler için finansal sektörde ise büyük ölçekli şirketler için geçerlidir. Ayrıca büyük şirketlerde küçük şirketlere göre, imalat sanayi şirketlerinde finansal șirketlere göre bulgular daha güçlüdür. Elde edilen bu bulgular hem imalat sanayi hem de finansal sektörde Borsa İstanbul şirketleri için temettü duyurularının pozitif fiyat etkisini doğrulamaktadır. Analizi.

Anahtar Kelimeler: Temettü, Borsa İstanbul, Normalüstü getiri, Temettü Değişimi, Temettü Verimi, Panel Veri

JEL Sinıflandirması: G300, G350

\begin{abstract}
Short Term Price Effect of Dividend Announcements in Manufacturing and Financial Sector: Evidence From Istanbul Stock Exchange

\section{ABSTRACT}

In this study, the shortterm price effect of the cash dividend distributions made to the share holders was investigated by using the event study method for manufacturing and financial sector companies registered to Istanbul Stock Exchange. For this purpose, 1.307 dividend announcements, between the years 2006-2018,were examined. It was analyzed whether there were abnormal returns in stock prices in the 3-day event window covering dividend distribution announcements. It was seen positive and negative abnormal return respectively in the dividend increase and decrease announcements. Smilarly, it was seen positive and negative abnormal return in the announcements with respectively high and low dividend yield announcements. In addition, as a result of the panel regressionanalysis, a positive relationship was found between the dividend yield/dividend Exchange variable and abnormal return variable in the event window.The results is more robust fo big firms than small firms and for manufacturing firms than financial firms. These findings confirmhe positive price effect of dividend announcements forIstanbul Stock Exchange companies in both the manufacturing and the financial industry.
\end{abstract} Analysis.

Keywords: Dividend, Istanbul Stock Exchange, Abnormal Return, Dividend Change, Dividend Yield, Panel Data

Jel Classification: G300, G350

\footnotetext{
${ }^{*}$ Bu çalışma, Balıkesir Üniversitesi Sosyal Bilimler Enstitüsü İşletme Anabilim Dalı doktora öğrencisi Devran DENİZ'in henüz tamamlanmamış olan doktora tezinin bir parçasıdır.

Makale Gönderim Tarihi: 26.04.2019,Makale Kabul Tarihi: 18.06.2019, Makale Türü: Araştırma Makalesi

** Doç. Dr., Bandırma Onyedi Eylül Üniversitesi, İktisadi ve İdari Bilimler Fakültesi, hokuyan@ bandirma.edu.tr: Orcid ID: 0000-0001-8960-8175.

*** Prof. Dr., Balıkesir Üniversitesi, İktisadi ve İdari Bilimler Fakültesi, sakarya@ balikesir.edu.tr, Orcid ID: 0000-0003-2510-7384.

**** Doç. Dr., Bandırma Onyedi Eylül Üniversitesi, İktisadi ve İdari Bilimler Fakültesi, caydin@ bandirma.edu.tr, Orcid ID: 0000-0002-0398-9884

***** Arş. Gör., Bandırma Onyedi Eylül Üniversitesi, İktisadi ve İdari Bilimler Fakültesi,

ddeniz@bandirma.edu.tr, Orcid ID: 0000-0003-3808-1929
} 


\section{GíRiş}

Nakit temettü dağııımlarının hisse senedi fiyatını nasıl etkileyeceği yönünde literatürdeçok sayıda teori bulunmaktadır. ${ }^{1}$ Eldeki kuş teorisi, sinyal teorisi gibi görüşler temettünün hisse senedi fiyatını artıracağını ifade ederken, vergi etkisi teorisi, yaşam döngüsü gibi teoriler ise tam tersini savunmaktadır. Şirketlerin ihraç maliyetleri de temettü dağıtımının negatif fiyat etkisi yaratmasına neden olan bir unsurdur. Temettü ilintisizlik teorisi ise mükemmel piyasalarda temettü dağıtımlarının hisse senedi fiyatını etkilemediğini savunmaktadır. ${ }^{2}$ Temettünün fiyat etkisi konusundaki teoriler arasındaki bu çelişkiyi Black (1976) "temettü bulmacası (dividend puzzle)" olarak ifade etmiş olup literatürde bu bulmacanın çözümüne katkı sunmak için çok sayıda ampirik çalışma yapılmıştır.

Gelişmiş ülke piyasalarında yüksek gözlem sayısı ile yapılan çalışmalarda nakit temettü dağıtımlarının hisse senedi fiyatına genellikle pozitif etkisi olduğu yönünde sonuçlar elde edilmişken, Türkiye ve Borsa İstanbul'daki şirketler özelinde yapılan araştırmalar birbirleri ile çelişkili sonuçlar vermiştir. Bu sebeple bu çalışmada Borsa İstanbul'a kayıtlı en büyük iki sektör olan imalat sanayi sektörü ve finansal sektörde uzun bir veri dönemi için nakit temettü duyurularının hisse senedi fiyatı üzerindeki kısa dönemli etkisi olup olmadığ 1 ve eğer böyle bir etki varsa bu etkinin ne yönde olduğu olay etüdü (casestudy) yöntemiyle incelenmiş̧tir.Yapılan literatür taramasından bu çalışmanın gözlem sayısı Türkiye'de yapılan çalışmalar arasından en yüksek olduğu anlaşılmaktadır. Ayrıca finansal sektörün incelenmesi ve hipotez testlerinde panel regresyon analizinin kullanılması da bu şekilde yapılmış sınırlı sayıda çalışmaya katkı sağlayacaktır.

Sonuçlar hem imalat sanayi ve finansal sektör için ayrı ayrı hem de alt sektörlere göre elde edilmiştir. Ayrıca şirket büyüklüğüne göre temettünün fiyat etkisinin farklılaşıp farklılaşmadığ da incelenmiştir. Son yıllarda Kamuyu Aydınlatma Platformu'nun yatırımcılar tarafindan daha etkin şekilde kullanılması olay etüdü yönteminin kullanıldığ bu çalışmada sonuçların güvenilirliğini artırması beklenmektedir. Çünkü KAP'ın yatırımcılar tarafindan etkin şekilde kullanılması kamuya açıklanan bilginin olay günü ve sonrasında piyasada hızlı şekilde yayılmasını sağlamaktadır.

Çalışmanın bundan sonraki kısmı olan literatür bölümünde konuyla ilgili yurt içi ve yurt dışı piyasalarda yapılmış araştırmalar anlatılmıştır. Bir sonraki kısım uygulama bölümünde ise hipotez ve metodoloji,veri seti, tanımlayıc istatistikler, analiz ve bulgular ve sağlamlık (robustness) testleriyer almaktadır. Sonuç bölümünde ise elde edilen bulgular değerlendirilmiş çalışmanın kısıtlarından bahsedilmiş ve bundan sonraki çalışmalar için önerilerde bulunulmuştur.

\section{LITTERATÜR}

Olay etüdü yöntemiyle temettü duyurularının hisse senedinin kısa dönemli fiyat etkisini araştran çok sayıda çalışma mevcuttur. Bu çalışmalarda temettü dağıtımlarının genellikle fiyatları pozitif yönde etkilediğine dair sonuçlar bulunmuştur (Aharony ve Dotan, 1994:125).Yani temettü artış duyuruları pozitif, temettü azalış duyuruları negatif normalüstü

\footnotetext{
${ }^{1}$ Çalışmanın bundan sonraki kısmında aksi belirtilmedikçe temettü ifadesiyle nakit temettü kastedilmiştir.

2 Ancak gerçek hayatta mükemmel piyasa varsayımlarını bozan işlem maliyetleri, vergi gibi bir çok faktör olduğu için bu görüş sadece temettü ile hisse senedi fiyatı ilişkisini açıklayan teorik bir görüş olarak kalmaktadır.
} 
getirilere yol açmaktadır. Değişim yaratmayan temettü duyuruları ise pay sahiplerine normal getiriler sağlamaktadır. $\mathrm{Bu}$ piyasa hareketi temettü duyuru etkisi (dividend announcementeffect)fenomeniolarak bilinmektedir (Gunasekarage ve Power, 2006:209-210).

Aharony ve Swary (1980) temettü duyurularının fiyat etkisini çalı̧an ilk araştırmacılardandır. Yazarlar imalat sanayi sektörüne ait 149 adet ABD şirketinin 3 bin 399 temettü duyurusunun fiyat etkisini araştırmıştır. Temettü duyuruları artış, azalış veya sabit (değişmeme) olarak 3 gruba ayrılmış ve olay gününün simetrik 10 günlük çevresinde toplam 21 gün için normalüstü getiriler incelenmiştir. Sonuçta olaydan bir gün öncesi ve olay günü normalüstü getiriler tespit edilmiştir. Temettü artı̧̧ları için pozitif, azalışları için negatif normalüstü getiriler bulunmuştur. Sonuçlar temettünün kısa dönemli pozitif fiyat etkisinidesteklemiştir.

Asquith ve Mullins (1983), 1954-1980 dönemi için NYSE'ye kayıtllı ABD şirketlerini incelemişlerdir. Yazarlar, ilk kez veya uzun bir aradan sonra ilk defa temettü ödemesi yapan şirketlerin 2 günlük normalüstü getirisinin pozitif $(\% 3,7)$ ve istatistiksel açıdan anlamlı olduğunu tespit etmiştir. Ayrıca yazarlar aynı şirketlerin devam eden yıllarda temettü artış duyurularında da temettü başlatmaya göre daha küçük olsa da pozitif normalüstü getiriler $(\% 2,07)$ sağladığını belirlemiştir.

Healy ve Palepu (1987) 1969-1980 dönemi için 303 adet NYSE'ye kayıtlı ABD şirketine ait temettü başlatma (initiation) ve sonlandırma (omission) duyurularının fiyat etkisini araştırmıştır. Araştırmacılar temettü başlatma duyurusu yapan firmaların ilk iki günde $\% 3,9$ pozitif, temettü sonlandırma duyurusu yapan firmaların ise duyuru günü $\% 9,5$ negatif normalüstü getiri sağladıklarını tespit etmiş̧ir. Söz konusu bulgular yatırımcıların temettü dağıtımlarına pozitif tepki verdiğini göstermiştir.

Bajaj ve Vijh (1990), Haw ve Kim (1991), Denis vd. (1994), Michaeley vd. (1995),Akhigbe ve Madura (1996) ABD,Suwanna (2012) Tayland, Hernandez (2017) Norveç, Berezinets vd. (2017) Hindistan, Aamir ve Shah (2011) ve Ali vd. (2017) Pakistan şirketleri için temettü değişimi ile piyasa tepkisi arasında pozitif yönlü ilişki bulan diğer araştırmacılardır.

Temettü duyurularının herhangi bir etkisi olmadığını tespit eden araştırmacılar da mevcuttur. Benartzi vd. (1997) ABD, Conroy ve Harris (2000) Japonya, Chen vd. (2002) Çin, Abeyratna ve Power (2002) İngiltere şirketleri için temettünün duyuru etkisi olmadığını tespit etmişlerdir (Vieira, 2005:3-4). Vieira (2005) Portekiz ve Fransa ve Qudah ve Badawi (2014) Suudi Arabistan şirketleri için temettü duyurularının fiyat etkisi yaratmadığını belirlemiştir. Yurtdışında yapılan çalışmalarda temettü duyurularının negatif fiyat etkisini tespit eden araştırmaya ise rastlanmamıştır.

Türkiye özelinde yapılan araştırmalarda ise birbiri ile zit yönlü sonuçlar veren araştırmalar bulunmaktadır. ${ }^{3}$ Yani hem temettü duyurularının pozitif etkisini hem de temettü

\footnotetext{
${ }^{3}$ Bunun nedeninin bazı çalışmalarda değişkenlerin seçimi ve hesaplamasında yapılan hatalar olduğunu düşünmekteyiz. Örneğin temettü değişimini, bir önceki yıla göre hisse başına temettü miktarındaki değişim olarak alınması tarafımızca hatalı sonuca neden olmaktadır. Çünkü yıldan yıla şirketlerin hisse senedi sayısı değişebilmekte bu durumda yıldan yıla hisse başına temettü tutarı da değişebilmektedir. Ayrıca hisse başına temettü tutarları arasındaki farkın ölçeği şirketten şirkete
} 
duyurularının negatif etkisinin tespit eden çalışmalar mevcuttur. Yılmaz ve Selçuk (2010), Kırbaş (2015), Arslan (2016), Başkaya (2012), Sakarya ve diğerleri (2017) temettü duyurularının pozitif ve anlamlı; Kadığlu (2008), Günalp vd. (2010) ve Kadığlu vd. (2015) ise temettü duyurularının negatif ve anlamlı fiyat etkisini tespit etmiştir. Temettü duyurularının negatif fiyat etkisini bulan 3 çalışmanın ortak özelliği bağımsız değişken olarak hisse başına temettü miktarınının kullanmasıdır. ${ }^{4}$

\section{UYGULAMA}

Uygulama kısmı, hipotez ve metodoloji, veri seti, tanımsal istatistikler, analiz ve bulgular ve sağlamlık (robustness) testi alt kısımlarından oluşmaktadır.

\subsection{Hipotez ve Metodoloji}

Nakit temettü duyurularının fiyat etkisi olay etüdü yöntemiyle araştırılmıştır. ${ }^{5}$ Olay günü olarak temettü dağıtımına dair yönetim kurulu kararının kamuya ilan edildiği yani KAP'a bildirildiği gün alınmıştır. ${ }^{6}$ Nitekim temettü duyurusu ilk kez kamuya açıklandığında fiyat tepkisi oluşmaktadır. ${ }^{7}$ Olay penceresi olarak olay günü çevresindeki simetrik 3 gün alınmıştır. Yani olay öncesi günü, olay günü ve olay sonrası günü olmak üzere olay penceresi toplam 3 günden oluşmaktadır. Olay öncesi günü bilginin önceden sızma ihtimalini, olay sonrası günü ise zayıf etkin piyasada bilginin piyasaya yayılma süresini içermektedir. Toplam 3 günlük süreç olayın etkisinin ölçülmesi için yeterli görülmüştür. Nitekim olay penceresi genişledikçe hisse senedi fiyatını etkileyen başka olaylar yaşanabilmekte ve araştırılan olayın etkisinin doğru ölçüm ihtimali azalmaktadır. ${ }^{8}$

Olay etüdü yönteminin uygulanışındaki en önemli sorun etkisi araştırılan olayla birlikte başka olayların da olması ve bu olayların etkisinin ayrıştırılamamasıdır (Günalp vd., 2010: 53) Örneğin temettü duyurularında sik rastlanabilecek durum temettü duyurularının mali tablolarla birlikte kamuya açıklanmasıdır. Bu durumda temettü duyurusunun net etkisini ölçmek zorlaşmaktadır. Ancak Türkiye'de yıl sonu mali tabloları o yıla ait temettü duyurularından genellikle çok daha erken açıklanmakta ve böyle bir sorun olmamaktadır. Nakit temettü ile hisse senedi temettü duyurularının birlikte açıklanmasına ise oldukça az sayıda rastlanmakta olup söz konusu duyuruların hariç tutulmasına gerek görülmemiştir.

farklılaşmaktadır. Bu durumda panel veri analizi yerine havuzlanmış en küçük karelerle regresyon analizi yapılması hatalı sonuçlara yol açabilmektedir.

${ }^{4}$ Tarafımızca, bağımsız değişken olarak temettü verimi, defter değerine oranlanan temettü değişimi gibi şirketler arasında standart bir ölçeği olan değişken kullanmak yerine hisse başına temettü miktarının kullanılması sonuçlarının tutarlılı̆̆ını etkilemediği düşünülmektedir. Çünkü her şirketin hisse senetlerinin piyasa fiyatı ve pay başına temettü miktarının ortalama seviyesi birbirinden farklıdır. Bu durumda hazvuzlanmış regresyon modeli kullanmanın sakıncaları vardır. Ayrıca şirketlerin yıldan yıla hisse senedi sayısının değişmesinin de sakıncaları bulunmakta doğrudan analiz sonucunu etkileyebilmektedir.

${ }^{5}$ Olay etüdü yöntemi (Case studymethod) kamuya açıklanan bir bilginin sürpriz sayılabilecek veya faydalı bir yönü varsa hisse senedinin piyasa değerini etkileyeceğini varsayan bir araştırma yöntemidir (Yılmaz ve Selçuk, 2010: 129).

${ }^{6} \mathrm{KAP}$ 'a bildirim saatinde BIST kapanmış veya resmi tatil günü ise bildirim tarihi olarak sonraki ilk iş günü alınmıştır. KAP platformundan önceki yıllar için ise temettü dağıtımına yönelik yönetim kurulu kararlarının Borsa İstanbul Günlük Bülteniyle duyurulduğu gün olay günü olarak alınmıştır.

7 Türkiye'de yönetim kurulu tarafından alınan temettü dağıtım kararları genel kurulda çoğunlukla kabul edilmekte ve bu sebeple yatırımcılar fiyat tepkisi için genel kurul kararını beklememektedir.

${ }^{8}$ Ayrıca yapılan analizlerde temettü duyurusu etkisinin genellikle duyuru günü olduğu ve bir gün öncesi ve sonrasında çok zayıf sayılabilecek etkiler tespit edildiği için 3 günlük olay penceresi yeterli görülmüş ve sonuçlar bu şekilde raporlanmıştır. 
Araştırmanın amacı hisse senedi fiyatlarının temettü duyurularına tepki gösterip göstermediğinin belirlenmesidir. Bunun için 2 araştırma hipotezi kurulmuştur. Bunlardan ilki,

$\mathrm{H}_{1 \mathrm{a}}$ : "Beklenmeyen temettü değişimi (temettü değişimi) ile olay penceresindeki normalüstü getiriler arasinda pozitif yönlü ilişki vardır." ş̧eklinde oluşturulmuştur.

Hipotezin bağımsız değişkenini hesaplamada yalın temettü değişimi yaklaşımı kullanılmıştır. Yani temettü tutarı rassal bir değişken olarak kabul edilerek duyurusu yapılan temettü tutarı ile bir önceki yılın temettüsü arasındaki fark beklenmeyen temettü değişimi olarak kabul edilmiştir. Bir başka ifade ile temettü değişiminin tamamı beklenmeyen temettü değişimi (unexpected dividend change) olarak alınmaktadır (Asquith ve Mullins, 1983:7796). ${ }^{9} \mathrm{Bu}$ nedenle beklenmeyen temettü değişimi (1) numaralı formülle hesaplanmış ve çalşsmanın bundan sonraki kısmında temettü değişimi ile beklenmeyen temettü değişimi eş anlamda kullanılmıştır.

$$
\Delta D i v_{i, t}=\frac{\left(D i v_{i, t}-D i v_{i, t-1}\right)}{B v_{i, t-1}}
$$

Bu denklemde

t $\quad$ : temettü duyurusunun yapıldığ 1 yılı

Divi, $:$ i şirketine ait t yılında duyurusu yapılan temettü miktarı

Diviti-1 $_{i, 1} \quad$ : i şirketine ait t-1 y1lında duyurusu yapılan temettü miktarı

$B V_{i, t-1} \quad$ : i şirketine ait t-1 yllının sonundaki öz kaynakların defter değeri

$\Delta \operatorname{Div}_{i, t}: \mathrm{i}$ şirketinin $\mathrm{t}$ yılında bir önceki yıla görestandartlaştırılmış temettü değişiminigöstermektedir.

Hipotezin bağımlı değişkeni olan normalüstü getiri ise düzeltilmiş piyasa getirisi modeli (adjusted market return model) kullanılarak aşağıdaki (2) nolu denklemle hesaplanmıştır. ${ }^{10}$

$$
A R(j)_{i, t}=R(j)_{i, t}-I R(j)_{i t}
$$

\footnotetext{
${ }^{9}$ Literatürde yalın temettü değişimlerine karşı eleştiriler bulunmaktadır. Çünkü yalın temettü değişimi beklenen veya beklenmeyen (piyasa açısından sürpriz olan) değişiklikleri birbirinden ayırt edemez. Çünkü model cari dönem kârını ve piyasanın en son beklentilerini içermemektedir (Kaymaz, 2010: 128). Bu sebeple ikinci bir yaklaşım olarak çeşitli regresyon modelleri kullanarak veya yatırım şirketlerinin tahmini doğrultusunda tamamlanmış hesap döneminin temettü tutarı tahmin edilmeye çalışılır. Gerçekleşen temettü ile tahmin edilen temettü arasındaki fark beklenmeyen temettü değişimi olarak kabul edilir (Kaymaz, 2010: 128). Bu yaklaşımın amacı temettü değişimlerinin sürpriz olan kısmının ölçülmesidir. Ancak beklenen temettünün hesaplanmasına yönelik literatürde bir kıstas bulunmamaktadır. Ayrıca beklenentemettü ölçümü sırasında yapılacak hata terimlerinin yaklaşımın sağlayacağı faydaları yok edip etmeyeceği de başka bir tartışma konusudur (Nissim ve Ziv, 2001: 2112). Türkiye özelinde şirketler için yapılmış geçmiş yıllara yönelik düzenli temettü tahminleri de bulunmamaktadır. Bütün bu sebeplerle bu araştırmada yalın temettü değişimi kullanılmıştır.

${ }^{10}$ Her ne kadar bazı çalıșmalarda riske göre düzeltilmiş piyasa getiri modeli (risk adjusted market return model) kullanılsa da, bazı sorunlarından dolayı düzeltilmiş piyasa getiri modelinden genellikle daha iyi sonuçlar üretmediğine dair araştırmalar vardır. Bu sebeple bu çalışmada düzeltilmiş piyasa getiri modeli tercih edilmiştir (Günalp vd., 2010: 58-59). Düzeltilmiş piyasa getiri modeli şirketin hisse senedi getirisinden piyasa endeks getirisinin çıkarılmasıyla hesaplanır (Healy ve Palepu, 1987: 10).
} 
Bu denklemde,

$A R(j)_{i, t} \quad:$ i şirketine ait t y1lındaki j gününe ait normalüstü getiriyi

$R(j)_{i, t}$ : i şirketine ait t y1lındaki j gününe ait getiriyi

$I R(j)_{i t}:$ i şirketin ait olduğu endekse ait t yılındaki $\mathrm{j}$ gününe ait getiriyi

göstermektedir. ${ }^{11}$

Analizde iki adet zaman boyutu olduğu için $\mathrm{t}$ ve $\mathrm{j}$ şeklinde iki zaman indisi kullanılmıştır. ${ }^{12}$ Burada $t$ temettü duyurusunun yapıldığı yılı göstermektedir. Diğer zaman indisi $\mathrm{j}$ ise temettü duyuru günü 0'1ncı gün kabul edilmek üzere olay gününe göre göreceli günü gösteren indistir. Yani;

$A R(-1)_{i, t} \quad$ : Temettü duyurusundan 1 gün önceki normalüstü getiriyi,

$A R(0)_{i, t} \quad$ : Temettü duyurusunun yapıldığı günkü normalüstü getiriyi,

$A R(1)_{i, t} \quad$ : Temettü duyurusundan 1 gün sonraki normalüstü getiriyi,

ifade etmektedir.

Olay penceresi 3 günden oluştuğundan toplam üç gün için kümülatif normalüstü getiri (3) numaralı formülle hesaplanmıştır.

$$
A R(a, b)_{i, t}=\sum_{j=a}^{b} A R(j)_{i t}
$$

Yani,

$A R(-1,-1)_{i, t} \quad$ :Temettü duyurusundan 1 gün önceki normalüstü getiriyi

$A R(0,0)_{i, t} \quad$ :Temettü duyuru günü normalüstü getiriyi

$A R(1,1)_{i, t} \quad$ :Temettü duyurusundan 1 gün sonraki normalüstü getiriyi

$A R(-1,1)_{i, t} \quad$ :Olay penceresindeki üç günlükkümülatif normalüstü getiriyi

göstermektedir. Söz konusu değişkenler her bir i şirketinin temettü duyurusu yapılan her bir $\mathrm{t}$ yılı için hesaplanmıştır. Daha sonra olay penceresi için ortalama kümülatif normalüstü getiri,n şirket sayısı, m zaman boyutunu göstermek üzere:

\footnotetext{
${ }^{11}$ Normalüstü getirilerin hesaplanmasında finansal şirketler için BİST Mali getiri endeksi, imalat sanayi şirketleri için BİST Sınai getiri endeksi kullanılmış, BİST100 veya BİST Tüm endeksleri tercih edilmemiştir. Buradaki amaç şirketin getirisinin bütün sektör şirketleri yerine sadece kendi sektörü ile karşılaştırılmasıdır. Böylelikle normalüstü getiri daha doğru ölçülmek istenmiştir. Ayrıca BİST Mali ve BİST Sınai endeksleri için fiyat endeksleri yerine getiri endeksleri tercih edilmiştir. Burada da amaç normalüstü getirileri en doğru şekilde ölçebilmektir. Çünkü getiri endeksleri şirketlerin dağıtmış olduğu nakit temettülere göre düzeltilmekte olduğu için fiyat endekslerine göre daha doğru karşılaştırma (benchmark) imkanı sağlamaktadır (www.borsaistanbul.com).

${ }^{12}$ Klasik havuzlanmış regresyon yöntemini kullanan araştırmacılar tek zaman indisi kullanmaktadır. Ancak panel regresyon yönteminde hem yatay hem zaman kesiti vardır ve birimlere (şirketlere) ait her bir verinin yıl bilgisi önemlidir (Güriş, 2015: 2).
} 


$$
A R(-1,1)=\frac{1}{n \cdot m} \sum_{i=1}^{n} \sum_{t=1}^{m} A R(-1,1)_{i t}
$$

formülüyle hesaplanmıştır. ${ }^{13}$ Buradaki amaç her bir i şirketinin her bir t yılındaki (1,1) olay penceresindeki normalüstü getirilerinin ortalamasının bulunmasıdır. Ayrıca olay penceresindeki üç günün her biri için de ayrı ayrı ortalama normalüstü getiriler $\operatorname{AR}(-1,-1)$, $\operatorname{AR}(0,0), \operatorname{AR}(1,1)$ benzer ölçümle hesaplanmıştır.

Araştırma hipotezi iki şekilde test edilmiştir. Bunlardan ilki için temettü duyuruları (yani bağımsız değişken) temettü dramatik azalış, azalış, artış, dramatik artış ve değişmeme olarak sınıflandırılmıştır. Sonra her bir grubunun olay penceresinde normalüstü getirilerinin (yani bağımlı değişken) sıfıra eşit olup olmadığı $t$ testi ile test edilmiştir. Bu yöntem sonuçları yalın bir şekilde görebilmek için Aharony ve Swary (1980), Asquith ve Mullins (1983)gibi araştırmacılar ile uyumlu şekilde yapılmış bir kategorik analizdir. İkinci test yöntemi ise bağımlı ve bağımsız değişkenler arasındaki ilişkinin panel regresyon analizi ile incelenmesidir. Bunun için tahmin edilecek panel regresyon denklemi aşağıdadır.

$$
\operatorname{AR}(-1,1)_{\mathrm{it}}=\beta_{0}+\beta_{1}^{*} \Delta \operatorname{Div}_{\mathrm{it}}+\varepsilon_{\mathrm{it}}
$$

Çalışmanın ikinci hipotezi ise;

$\mathrm{H}_{2 \mathrm{a}}$ : "Temettü verimleri ile olay penceresindeki normalüstü getiriler arasında pozitif yönlü ilişki vardır." ş̧eklinde oluşturulmuştur.

$\mathrm{Bu}$ hipotez yalın temettü değişiminin bahsedilen sakıncalarından kurtulabilmek amacıyla oluşturulmuştur. Çünkü temettü verimi şirketler ve yıllar arasında aynı ölçekte objektif olarak ölçülebilen bir değişkendir. ${ }^{14}$ hesaplanmıştır.

Hipotezin bağımsız değişkeni olan temettü verimi (6) numaralı formülle

$$
D Y_{i t}=D P S_{i t} / P(-2)_{i t}
$$

DY $Y_{\text {it }} \quad$ : i şirketinin t yılı içintemettü verimi (dividend yield)

DPS $_{\text {it }}$ : i şirketinin t yılında açıklanan hisse başına brüt temettü miktarı (Dividend Per Share),

$\mathrm{P}(-2)_{\text {it }}$ : i şirketinin $\mathrm{t}$ yllında temettü duyurusundan 2 gün önceki düzeltilmemiş hisse fiyatını göstermektedir. ${ }^{15}$

\footnotetext{
13 Bütün şirketler için zaman boyutu aynı olmayıp, (4) numaralı denklem gösterim amaçlıdır. “AR(-1,1)= Ortalama(AR(-1,1) $\left.)_{\text {it }}\right)$ bütün (i,t) ikilileri için" şeklinde göstermek daha doğrudur

14 Örneğin bir şirketin temettü duyurusu \%5 denildiğinde, o şirketin fiyatından ve geçmiş yıl dağıttığı temettüden bağımsız olarak fiyatının \%5'i kadar temettü dağıtımı yaptığı anlaşılmaktadır.

${ }^{15}$ Literatürde de genellikle temettü duyurusu veriminin hesaplanması için duyurudan 2 önceki hisse senedi fiyatı kullanılmaktadır. Çünkü etkin piyasalar kuramı gereği duyurudan birkaç gün önceki hisse senedi fiyatının kamuya çıklanmış olan yıllık kâr bilgisi dahil bütün bilgileri yansıttığ 1 kabul edilmektedir. Bu fiyat üzerinden hesaplanan temettü veriminin seviyesi (yüksek veya düşük oluşu) piyasanın en güncel beklentilerinin ötesinde önemli bir bilgi olarak görülmektedir. Nitekim temettü duyurusunu hisse senedi fiyat etkisi yaratan kısmı piyasanın beklediğinden farklı yani temettünün sürpriz olan kısmıdır.
} 
Hipotezin bağımlı değişkeni olay penceresindeki normalüstü getirinin hesaplanması yukarıda anlatılmıştır.

$\mathrm{H}_{2 \mathrm{a}}$ hipotezi hem kategorik olarak hem de panel regresyon analizi ile test edilmiştir. Öncelikle duyurular temettü veriminin yüksek veya düşük olmasına göre ortanca değerden (medyan) iki gruba ayrılmış ve her iki grubun olay penceresinde ortalama normalüstü getirisi hesaplanmıştır. Hem grupların ortalamasının birbirinden hem de her bir grubun ortalamasının sıfırdan farklı olup olmadığ 1 test edilmiştir. Hipotez ikinci yöntem olarak panel veri analizi ile test edilmiştir. Tahmin edilecek panel regresyon denklemi (7) nolu eşitlikte gösterilmiştir.

$$
\operatorname{AR}(-1,1)_{\mathrm{it}}=\beta_{0}+\beta_{1}^{*} \mathrm{DY} \mathrm{Yit}_{\mathrm{it}}+\varepsilon_{\mathrm{it}}
$$

Hipotezlerin test sonuçlarına geçmeden önce temettü dağıtımlarına ilişkin kullanılan veri seti ve tanımsal istatistikler aşağıda sırasıyla sunulmuştur.

\subsection{Veri Seti}

Çalışmanın veri setini 2006-2018 döneminde en az bir kez temettü dağıtan finansal ve imalat sanayi sektör şirketleri oluşturmaktadır. ${ }^{16}$ Söz konusu dönemde 179 imalat sanayi şirketinden 115'i, 128 finansal şirketten 92'si en az bir kez temettü dağıtımı yapmıştır. Bu şekilde imalat sanayi ve finansal sektör şirketlerine ait toplam 1.702 temettü duyurusuna ulaşılmıştır. Ancak yarattığı sakıncalardan dolayı bazı gözlemler veri setinden çıkarılmıştır. ${ }^{17}$ Ayrıca 2006 yılına ait temettü değişimi de bir önceki yılın tutarının bilinmemesi nedeniyle hesaplanamamaktadır.Bütün bunların sonunda nihai olarakimalat sanayi şirketlerine ait 859, finansal şirketlere ait 567 olmak üzere toplam 1.426 değişimi hesaplanabilen temettü duyurusu (olay günü) elde edilmiştir.

Çalışmada kullanılan hisse senedi fiyat bilgileri (düzeltilmiş ve düzeltilmemiş fiyat) Finnet ve Matriks veri dağıtım şirketlerinden temin edilmiştir. BİST İmalat Sanayi ve BİST Finansal Sektör getiri endeksleri TCMB elektronik veri dağıtım sisteminden elde edilmiştir ${ }^{18}$ Nitekim normalüstü getirinin hesaplanmasında hisse senedi fiyatları için düzeltilmiş fiyat kullanıldığı için Benchmark olarak da getiri endeksi tercih edilmiştir. Temettü duyuru tarihleri ve açıklanan temettü tutarları KAP, Finnet haber expertmodülü ve İş Yatırım web sayfasından temin edilmiş ve doğrulukları birbirleriyle kontrol edilmiştir. Şirketlerin öz kaynaklarının defter değeri de Finnet veri dağıtım şirketinden temin edilmiştir. Ayrıca analizlerin uç değerlerden (outlier) etkilenmemesi için bağımlı ve bağımsız değişkenler \%95 seviyesinde winsorize edilmiştir. Winsorize ederek uç değerlerin analizden tamamen çıkarılmasına yani veri kaybına engel olunmaktadır. ${ }^{19}$

\footnotetext{
16 Söz konusu dönemde temettü dağıtımını değiştiren önemli bir yasal değişiklik olmamıştır. Ayrıca periyod olarak daha eski yıllara gidildikçe şirketlere ait duyuruların piyasaya yayılma hızının son yıllardaki kadar yüksek olmadığı düşünülmektedir.

${ }^{17}$ Birden fazla temettü dağıtımı yapılan yılın temettü duyuruları, genel kurul ve yönetim kurulu arasındaki ihtilaf veya başka bir nedenle aynı yılın temettü tutarına ait sık sık değiştirilen temettü duyuruları, temettü avansı ödemesine dair duyurular ve çalışma döneminin ilk yıllarında halka açık şirket sayılması sebebiyle KAP'a temettü dağıtım kararlarının duyurusunu yapan ancak borsaya kote olmayan bu sebeple hisse senedi piyasa fiyatları olmayan şirketlerin o yıllardaki duyuruları analizden çıkarılmıştır.

18 Borsa İstanbul'da endeksler fiyat ve getiri endeksi olmak üzere 2 şekilde hesaplanmaktadır. Fiyat endeksleri ödenen nakit temettüleri dikkate almadığından Borsa performansını olduğundan daha düşük göstermektedir. Getiri endeksleri ise ödenen nakit temettülerin endeksteki hisse senetlerine ağırlıkları oranında tekrar yatırıldı̆̆ını dikkate alarak hesaplanır (www.borsaistanbul.com). Bu yönüyle getiri endeksi fiyat endeksine göre daha doğru bir benchmark olarak kabul edilmektedir (https://cleartax.in/s/total-return-vs-price-return-index, 19.03.2019).

${ }^{19}$ Bir değişkenin winsorize edilmesi istatistiksel analizin uç değerlerden etkilenmemesi için o değişkenin dağılımının istenen bir aralığa sıkıştırılmasıdır (Cebenoyan ve Strahan, 2004: 26). Örneğin bir değişkenin \%90 seviyesinde winsorize edildiğinde, değişkeni ilk \%5'lik
} 


\subsection{Tanımsal İstatistikler}

Bu kısımda 2006-2018 dönemi için Borsa İstanbul şirketlerinin temettü dağıtımları hakkında bilgiler veren tanımlayıcı istatistikler sunulmuştur. Çalışma dönemi boyunca derlenen verilerden elde edilen istatistiklerin sunulmasının faydalı olacağı düşünülmektedir. Tablo 1'de 2006-2018 dönemi boyunca dağıtılan toplam brüt nakit temettü tutarı sektör ve alt sektörler bazında sunulmuştur. İmalat sanayi şirketleri 63,2 milyar TL, finansal şirketler ise 54,7 milyar TL brüt nakit temettü ödemesi gerçekleştirmiştir. İmalat sanayi sektöründe en büyük pay1 \%32,1 ile kimya petrol ve plastik sanayi alt sektörü almıştır. Finansal sektörde ise bankalar ve finans kurumları tek başına temettü ödemelerinin \%58,3'ünü gerçekleştirmiştir. Holding ve yatırım şirketleri ile beraber bu iki sektörün oranı yaklaşık \%86'ya yükselmektedir. Gayrimenkul yatırım ortaklıkları dahil ilk üç alt sektörün temettü ödemeleri ise finansal sektörün neredeyse tamamını (\%95) oluşturmaktadır.

Tablo 1. 2006-2018 Döneminde Sektörel Bazda Temettü Dağıtım Tutarları

\begin{tabular}{|c|c|c|c|c|}
\hline Sira & Sektör & Alt Sektör & $\begin{array}{c}\text { Toplam Brüt } \\
\text { Temettü } \\
\text { Miktarı (Milyar } \\
\text { TL) }\end{array}$ & $\begin{array}{c}\text { Sektör İçindeki } \\
\text { Payı }\end{array}$ \\
\hline 1 & İmalat Sanayi & Kimya Petrol Plastik & 20.3 & $32.1 \%$ \\
\hline 2 & İmalat Sanayi & Metal Ana Sanayi & 14.7 & $23.3 \%$ \\
\hline 3 & İmalat Sanayi & Metal Eşya & 11.7 & $18.6 \%$ \\
\hline 4 & İmalat Sanayi & Taş ve Toprağa Dayalı Sanayi & 10.1 & $16.0 \%$ \\
\hline 5 & İmalat Sanayi & Gıda İçki Tütün & 5.0 & $7.8 \%$ \\
\hline 6 & İmalat Sanayi & Dokuma Giyim Deri & 0.7 & $1.1 \%$ \\
\hline 7 & İmalat Sanayi & Kağıt Ürünleri Basım Yayın & 0.5 & $0.8 \%$ \\
\hline 8 & İmalat Sanayi & Diğer İmalat & 0.2 & $0.2 \%$ \\
\hline \multirow[t]{2}{*}{9} & İmalat Sanayi & Orman Ürünleri ve Mobilya & 0.1 & $0.1 \%$ \\
\hline & & Alt Toplam & 63.2 & $100 \%$ \\
\hline 10 & Finansal Sektör & Banka ve Finans Kurumları & 31.9 & $58.3 \%$ \\
\hline 11 & Finansal Sektör & Holding ve Yatırım Şirketleri & 15.1 & $27.7 \%$ \\
\hline 12 & Finansal Sektör & Gayrimenkul Yatırım Ortaklıkları (GYO) & 4.9 & $9.0 \%$ \\
\hline 13 & Finansal Sektör & Sigorta & 1.7 & $3.2 \%$ \\
\hline 14 & Finansal Sektör & Aracı Kurumlar & 0.4 & $0.7 \%$ \\
\hline 15 & Finansal Sektör & Menkul Kıymet Yatırım Ortaklıkları (MKYO) & 0.3 & $0.5 \%$ \\
\hline 16 & Finansal Sektör & Leasing ve Faktoring & 0.2 & $0.5 \%$ \\
\hline 17 & Finansal Sektör & Girişim Sermayesi Yatırım Ortaklığ1 (GSYO) & 0.1 & $0.2 \%$ \\
\hline & & Alt Toplam & 54.7 & $100 \%$ \\
\hline
\end{tabular}

diliminin 5. yüzdeliğe (5. percentile), son \%5'lik dilimi ise 95. yüzdeliğe (95. Percentile) sabitlenmektedir. Ampirik çalışmalarda genellikle $\% 95$ veya $\% 99$ seviyesinde winsorize etme işlemine rastlanmaktadır. 
Tablo 2'de çalışma dönemi için sektörelbazda temettü verimleri gösterilmiştir. Son 12 yılda imalat sanayi şirketleri \%7.84, finansal şirketler ise $\% 3.58$ ortalama temettü verimi sağlamıştır. $\mathrm{Bu}$ durum imalat sanayi şirketlerinin daha çok temettü kazancı, finansal şirketlerin ise sermaye kazancı sağladığını işaret etmektedir. Bir başka ifade ile finansal kurumlar iç kaynakları daha çok temettü olarak dağıtmak yerine genellikle yeniden yatırıma daha fazla yöneltmektedir

Alt sektörler bazında imalat sanayi sektöründe metal ana sanayi (\%9.36), kimya petrol plastik (\%8.93), kağıt ürünleri basım ve yayın (\%8.85) alt sektörleri; finansal sektörde ise MKYO (\%14.83), leasing ve faktöringlerin (\%12.47) yüksek temettü verimi sağladığ görülmektedir. Banka ve finans kurumları ile holding ve yatırım şirketlerinin düşük temettü verimi sağladığı görülmektedir.

Tablo 2. 2006-2018 Döneminde Sektörlere Göre Temettü Verimleri ${ }^{20}$

\begin{tabular}{|c|c|c|c|}
\hline Sektör & Alt Sektör & $\begin{array}{c}\text { Toplam } \\
\text { Temettü } \\
\text { (Milyar TL) }\end{array}$ & $\begin{array}{l}\text { Temettü } \\
\text { Verimi }\end{array}$ \\
\hline İmalat Sanayi & Metal Ana Sanayi & 14.7 & $\% 9.36$ \\
\hline İmalat Sanayi & Kimya Petrol Plastik & 20.3 & $\% 8.93$ \\
\hline İmalat Sanayi & Kağıt Ürünleri Basım ve Yayın & 0.5 & $\% 8.85$ \\
\hline İmalat Sanayi & Taş ve Toprağa Dayalı Sanayi & 10.1 & $\% 8.16$ \\
\hline İmalat Sanayi & Dokuma Giyim Deri & 0.7 & $\% 7.75$ \\
\hline İmalat Sanayi & Metal Eşya & 11.7 & $\% 5.79$ \\
\hline İmalat Sanayi & Diğer İmalat & 0.2 & $\% 5.55$ \\
\hline İmalat Sanayi & Orman Ürünleri ve Mobilya & 0.1 & $\% 5.26$ \\
\hline \multirow[t]{2}{*}{ İmalat Sanayi } & Gıda İçki Tütün & 5.0 & $\% 3.03$ \\
\hline & Alt Toplam & 63.2 & $\% 7.84$ \\
\hline Finansal Sektör & Menkul Kıymet Yatırım Ortaklıkları & 0.3 & $\% 14.83$ \\
\hline Finansal Sektör & Leasing ve Faktoring & 0.2 & $\% 12.47$ \\
\hline Finansal Sektör & Aracı Kurumlar & 0.4 & $\% 8.65$ \\
\hline Finansal Sektör & Girişim Sermayesi Yatırım Ortaklığ & 0.1 & $\% 7.54$ \\
\hline Finansal Sektör & Gayrimenkul Yatırım Ortaklıkları & 4.9 & $\% 5.85$ \\
\hline Finansal Sektör & Sigorta & 1.7 & $\% 5.29$ \\
\hline Finansal Sektör & Holding ve Yatırım Şirketleri & 15.1 & $\% 3.54$ \\
\hline \multirow[t]{3}{*}{ Finansal Sektör } & Banka ve Finans Kurumları & 31.9 & $\% 2.92$ \\
\hline & Alt Toplam & 54.7 & $\% 3.58$ \\
\hline & Genel Toplam/Ortalama & 117.9 & $\% 5.84$ \\
\hline
\end{tabular}

Tablo 3'de ise sektörelbazda temettü dağıtım oranları (Dividend Payout Ratio-DPR) sunulmuştur. ${ }^{21}$ İmalat sanayiinde (\%54) temettü dağıtım oranı finansal sektöre göre (\%18.6) çok daha yüksektir. Alt sektörler bazındaki sonuçlar temettü verimi ve tutarı için olan

\footnotetext{
${ }^{20}$ Temettü verimleri yalnızca temettü dağıtımı yapılan duyuruların ortalamasını yansıtmaktadır. Temettü dağıtımı yapılmayan duyurular dikkate alındığında bu oran daha düşük çıkacaktır.

${ }_{21}$ Temettü dağıtım oranı dağıtılabilir kârın ortaklara dağıtılan rasyosudur. SPK tarafından yayınlanan Kâr Payı Rehberinde (KPR) net dağıtılabilir dönem karı; "net dönem karından varsa geçmiş yıllar zararlarının ve genel kanuni yedek akçenin düşülmesi ile bulunan tutar" olarak tanımlanmıştır. Ayrıca bağışlar dağıtılabilir kâra eklenmektedir. 207 şirketin 12 yıllık dönemdeki söz konusu verilerin ulaşmanın zorluğundan dolayı net kâr yaklaşık dağıtılabilir kâr olarak kabul edilmiştir.
} 
sonuçlara benzerdir. Örneğin finansal sektörde en düşük temettü dağıtım oranı banka ve finans kurumları (\%16.7) ile holding ve yatırım şirketi (\%19.8) alt sektörlerine aittir.

Tablo 3. Sektörlere Göre Temettü Dağıtımı Oranları (DPR) ${ }^{22}$

\begin{tabular}{|l|l|c|c|}
\hline Sektör & Alt Sektör & $\begin{array}{c}\text { Toplam } \\
\text { Temettü } \\
\text { (Milyar } \\
\text { TL) }\end{array}$ & $\begin{array}{c}\text { Tem. Dağ. } \\
\text { Oranı } \\
\text { (DPR) }\end{array}$ \\
\hline İmalat Sanayi & Dokuma Giyim Deri & 0,7 & $\% 64.2$ \\
\hline İmalat Sanayi & Kimya Petrol Plastik & 20.3 & $\% 59.9$ \\
\hline İmalat Sanayi & Taş ve Toprağa Dayalı Sanayi & 10.1 & $\% 56.2$ \\
\hline İmalat Sanayi & Metal Ana Sanayi & 14.7 & $\% 53.9$ \\
\hline İmalat Sanayi & Kağı Ürünleri Basım Yayın & 0,5 & $\% 52.8$ \\
\hline İmalat Sanayi & Metal Eşya & 11.7 & $\% 52.4$ \\
\hline İmalat Sanayi & Orman Ürünleri ve Mobilya & 0,1 & $\% 47.8$ \\
\hline İmalat Sanayi & Diğer İmalat & 0,2 & $\% 47.2$ \\
\hline İmalat Sanayi & Gıda İçi Tütün & 5.0 & $\% 38.2$ \\
\hline & Alt Toplam/Ortalama & $\mathbf{6 3 . 2}$ & $\mathbf{\% 5 4 . 0}$ \\
\hline Finansal Sektör & Menkul Kıymet Yatırım Ortaklıkları & 0.3 & $\% 93.9$ \\
\hline Finansal Sektör & Sigorta & 1.7 & $\% 53.1$ \\
\hline Finansal Sektör & Leasing ve Faktoring & 0.2 & $\% 45.5$ \\
\hline Finansal Sektör & Aracı Kurumlar & 0.4 & $\% 42.1$ \\
\hline Finansal Sektör & Girişim Sermayesi Yatırım Ortaklığı & 0.1 & $\% 30.0$ \\
\hline Finansal Sektör & Gayrimenkul Yatırım Ortaklıkları & 4.9 & $\% 23.3$ \\
\hline Finansal Sektör & Holding ve Yatırım Şirketleri & 15.1 & $\% 19.8$ \\
\hline Finansal Sektör & Banka ve Finans Kurumları & 31.9 & $\% 16.7$ \\
\hline & Alt Toplam & $\mathbf{5 4 . 7}$ & $\mathbf{\% 1 8 . 6}$ \\
\hline Genel Toplam/Ortalama & $\mathbf{1 1 7 . 9}$ & $\mathbf{\% 2 8 . 7}$ \\
\hline
\end{tabular}

\subsection{Analiz ve Bulgular}

Tablo 4'de $\mathrm{H}_{1 \mathrm{a}}$ hipotezi için kategorik analiz sonuçları bulunmaktadır. Görüldüğg̈ gibi imalat sanayi sektöründeki şirketler için $\mathrm{H}_{1 \mathrm{a}}$ araştırma hipotezini destekleyen sonuçlar elde edilmiştir. Dramatik ve 1lımlı temettü azalışları için negatif, dramatik temettü artışları için pozitif normalüstü getiriler ölçülmüştür. Ilımlı temettü artışlarına ise yatırımcılar istatistiksel açıdan anlamlı bir tepki göstermemiştir. $\mathrm{Bu}$ sonuçlar temettünün pozitif fiyat etkisini desteklemektedir. Ancak dramatik azalışlarda tepkinin 1lımlı azalışlara göre daha sert olması beklentisi gerçekleşmemiştir. Finansal şirketlerde ise sadece dramatik temettü artışları için pozitif normalüstü getiri tespit edilmiştir. Bu bulgu finansal sektörde temettünün fiyat etkisini temettü artışları özelinde destekleyen bir sonuçtur.

${ }^{22}$ Temettü dağıtım oranı yalnızca dağııım yapan şirketler için ölçülmüştür. Temettü dağıtmayan şirketler dikkate alınırsa bu oran daha düşük çıkacaktır. 
Tablo 4. Temettü Değişimine Göre Hisse Senedi Fiyat Tepkileri

\begin{tabular}{|l|c|c|c|c|c|c|}
\cline { 2 - 7 } \multicolumn{1}{c|}{} & \multicolumn{3}{c|}{ İmalat Sanayi } & \multicolumn{3}{c|}{ Finansal } \\
\cline { 2 - 7 } & $\begin{array}{c}\text { Gözlem } \\
\text { Sayısı }\end{array}$ & $\begin{array}{c}\text { Ort. Tem. } \\
\text { Değ. }\end{array}$ & $\begin{array}{c}\text { Normalüstü } \\
\text { getiri (\%) }\end{array}$ & $\begin{array}{c}\text { Gözlem } \\
\text { Sayıs1 }\end{array}$ & $\begin{array}{c}\text { Ort. } \\
\text { Tem } \\
\text { Değ. }\end{array}$ & $\begin{array}{c}\text { Normalüstü } \\
\text { getiri (\%) }\end{array}$ \\
\hline Azalış (Dramatik) & 160 & $-8.1 \%$ & $\mathbf{- 0 . 6 2 * *}$ & 93 & $-6.2 \%$ & -0.01 \\
\hline Azalış (Ilımlı) & 159 & $-1.4 \%$ & $\mathbf{- 0 . 9 7 * *}$ & 93 & $-0.7 \%$ & -0.22 \\
\hline Artış (Ilımlı) & 235 & $1.4 \%$ & -0.42 & 161 & $0.5 \%$ & 0.13 \\
\hline Artış (Dramatik) & 235 & $8.0 \%$ & $\mathbf{0 . 9 6 * * *}$ & 161 & $4.5 \%$ & $\mathbf{0 . 6 2} * *$ \\
\hline
\end{tabular}

$*, * *, * * *$ sirasiyla $\% 10, \% 5$ ve $\% 1$ anlamlllık seviyesini göstermektedir.

Tem. Değ. $=\Delta$ Div/BV olmak üzere, ortalama temettü değişimi her bir kategorideki temettü değişimlerinin ortalaması alınarak hesaplanmıştır.

Tablo 5'te ise temettü verimine göre hisse senedi fiyat tepkileri görülmektedir $\left(\mathrm{H}_{2 \mathrm{a}}\right.$ hipotez testi sonuçları). İmalat sanayi sektöründe temettü verimi düşük olan duyurularda negatif (-\%1.02), temettü verimi yüksek olanduyurularda ise pozitif normalüstü getiri $(\% 0,60)$ ölçülmüştür. Söz konusu getiriler \%99 güven seviyesinde sıfırdan farklıdır. Aynı zamanda aralarındaki fark da $(\% 1,62)$ istatistiksel açıdan anlamlıdır $(\mathrm{p}=0,00)$. Finansal sektör duyurularında da benzer sonuçlar vardır. $\mathrm{H}_{1 a}$ hipotez sonucuna benzer şekilde temettü veriminin yüksek olması pozitif fiyat etkisi yaratmıştır $(\% 0,60)$. Ancak temettü verimi düşük olan duyurular anlamlı negatif fiyat etkisine $(-\% 0,29)$ neden olmamıştır. Fakat her iki duyuru grubunun ortalamasi arasındaki fark $(\% 0,89)$ anlamlıdır.Dolayısıyla $\mathrm{H}_{2 \mathrm{a}}$ hipotezini destekleyen bulgular elde edilmiştir. Sonuçlar $\mathrm{H}_{1 \mathrm{a}}$ hipotezi test sonuçlarına oldukça benzerdir.

Tablo 5. Temettü Verimine Göre Hisse Senedi Fiyat Tepkileri

\begin{tabular}{|l|c|c|c|c|}
\hline & \multicolumn{2}{|c|}{$\begin{array}{c}\text { Imalat Sanayi } \\
\text { Gözlem:859 }\end{array}$} & \multicolumn{2}{c|}{$\begin{array}{c}\text { Finansal } \\
\text { Gözlem:567 }\end{array}$} \\
\hline & Düşük & Yüksek & Düşük & Yüksek \\
\hline Temettü Verimi Ort. & $1.42 \%$ & $8.00 \%$ & $0.82 \%$ & $6.46 \%$ \\
\hline Gözlem Sayıs1 & 429 & 430 & 284 & 283 \\
\hline $\begin{array}{l}\text { Normalüstü getiri (\%) } \\
\text { (t değeri) }\end{array}$ & $\mathbf{- 1 . 0 2}$ & $\mathbf{0 . 6 0}$ & -0.29 & $\mathbf{0 . 6 0}$ \\
\hline Fark (\%) & $(-5.16)$ & $(3.09)$ & $(-1.21)$ & $(3.09)$ \\
\hline
\end{tabular}

***: \%1 seviyesinde anlamlıl̆̆ ifade etmektedir.

Temettü verimi= Hisse başına temettü/ Hisse fiyatı, Hisse fiyatı temettü duyurusundan 2 gün önceki fiyat olarak alınmıştır (Denklem (6)).

Özetle her iki hipotezin kategorik analiz sonuçlarından, imalat sanayi ve finansal sektörde temettünün pozitif fiyat etkisine ulaşılmıştır. İmalat sanayi sektöründe temettü duyurularının fiyat etkisi finansal sektöre göre daha güçlüdür (ortalama normalüstü getiri ve t istatistikleri mutlak değerce daha büyük). Finansal sektör duyurularının fiyat etkisi temettü artış1 veya yüksek temettü verimi olan duyurularda geçerlidir. Yani finansal sektörde düşük temettü duyurusu anlamlı bir negatif etki yaratmamaktadır. 
Tablo 6 ve Tablo 7'desırasiyla $\mathrm{H}_{1 \mathrm{a}}$ ve $\mathrm{H}_{1 \mathrm{~b}}$ hipotezlerinin panel regresyon analizi test sonuçları sunulmuştur. Tablo 6'da temettü değişimi ile normalüstü getiri arasındaki ilişkinin panel regresyon tahmin sonuçları bulunmaktadır. Olay penceresindeki 3 günden anlamlı etkinin sadece olay gününde olduğu görünmektedir. Bu durum bilginin piyasaya duyuru gününde yansıdığı ve yansıma süresinin daha uzun sürmediğini bir başka ifade ile piyasanın etkinliğini göstermektedir. $(-1,1)$ olay penceresinde her iki sektör için de pozitif ve \%1 seviyesinde anlamlı regresyon katsayısı $(0,11)$ elde edilmiştir. Regresyon katsayıları aynı olup $\mathrm{t}$ istatistiği imalat sanayi sektörü için daha büyüktür. Sonuçlar her iki sektör için $\mathrm{H}_{1 \mathrm{a}}$ hipotezini yani temettünün pozitif yönlü fiyat etkisini desteklemektedir.

Tablo 6. Temettü Değişimi ile Normalüstü Getiri Arasındaki İlişki Panel Regresyon Tahmincileri

\begin{tabular}{|c|c|c|c|c|}
\hline \multicolumn{5}{|c|}{$A R(a, b)_{i t}=\beta_{0 i}+\beta_{1} . \Delta D_{i v_{i t}}+\varepsilon_{i t}$} \\
\hline & \multicolumn{2}{|c|}{$\begin{array}{c}\text { İmalat Sanayi } \\
\text { (859 gözlem) }\end{array}$} & \multicolumn{2}{|c|}{$\begin{array}{c}\text { Finansal Sektör } \\
\text { (567 gözlem) }\end{array}$} \\
\hline $\begin{array}{c}\text { Olay } \\
\text { Pencereleri }\end{array}$ & $\begin{array}{c}\text { RegresyonKatsayıs } 1 \\
\left(\beta_{1}\right)\end{array}$ & $\mathrm{t}$ istatistiği & $\begin{array}{c}\text { RegresyonKatsayısı } \\
\left(\beta_{1}\right)\end{array}$ & $\mathrm{t}$ istatistiğ $\mathrm{i}$ \\
\hline$(-1,-1)$ & 0.02 & 1.44 & 0.00 & -0.25 \\
\hline$(0,0)$ & $0.09 * * *$ & 4.36 & $\mathbf{0 . 0 9} * *$ & 2.36 \\
\hline$(1,1)$ & 0.01 & 0.63 & 0.01 & 0.03 \\
\hline$(-1,1)$ & $0.11 * * *$ & 4.03 & $0.11 * *$ & 2.43 \\
\hline
\end{tabular}

***,**,* sirasıly $\% 1, \% 5$ ve $\% 10$ seviyesinde anlamlılığ 1 ifade etmektedir.

$\mathrm{AR}(\mathrm{a}, \mathrm{b})_{\mathrm{it}}=\mathrm{i}$ şirketinin $\mathrm{t}$ yılındaki temettü duyuru gününe göre a ve b günleri arasındaki normalüstü getirisi (Denklem 3). $\Delta \operatorname{Div}_{\text {it }}=\mathrm{i}$ şirketinin $\mathrm{t}$ yılındaki temettü değişim oranı (Denklem 1 ).

Panelde zaman etkisi gözlenmemiş birim etkisinin varlığı tespit edilmiştir. Bu sebeple tek yönlü (birim etkili) panel regresyon modeline karar verilmiştir. Hem önsel bilgiler hem de Hausman testi sonucunda tek yönlü sabit etkiler modeli tercih edilmiştir. Otokorelasyon ve yatay kesit bağımlılığına rastlanmamış ancak değişen varyans problemine rastlanmıştır. Bu nedenle nihai olarak tek yönlü (birim etkili) sabit etkiler modelinde değişen varyans problemine karşı dirençli olan White (1980) tahmincisi kullanılmıştır. Ayrıca 1. nesil birim kök testleri (Levin, Lin ve Chu (1992) ve Hadri (2000) testleri) ile bağımlı ve bağımsız değişkenin durağanlığı kontrol edilmiş ve birim köke rastlanmamıştır. Yapılan testlere ait sonuçlar makalenin sayfa sayısını artırmamak amacıyla verilmemiş olup, hakem veya okuyucuların talep etmesi halinde paylaşılabilir.

Tablo 7'de ise temettü verimi ile normalüstü getiri arasındaki ilişki için panel regresyon tahmin sonuçları bulunmaktadır. Sonuçlar $\mathrm{H}_{2 \mathrm{a}}$ hipotezini desteklemekte olup Tablo 6'dakine benzerdir. Bütün günler ve olay penceresindeki regresyon katsayıları ve t istatistikleri imalat sanayi sektörü için finansal sektöre göre daha büyüktür. Ancak Tablo 6'dan farklı olarak olay öncesi ve sonrası günler için de katsayılar anlamlı bulunmuştur. Bu sonuç duyuruya verilen tepkiyi temettü veriminin temettü değişimine göre daha iyi açıkladığına işaret etmektedir. Ayrıca bu sonuç imalat sanayi sektöründe temettü duyurusundan önceki bir gün için içeriden öğrenenler ticareti (insidertrading) yapıldığını göstermektedir. Olayın etkisinin olaydan bir gün sonraya sarkması ise normaldir. Çünkü borsa seansı kapanmak üzere gelen duyurular böylesi bir sonuca neden olabilir. 
Tablo 7. Temettü Verimi ile Normalüstü Getiri Arasındaki İlişki Panel Regresyon Tahmincileri

\begin{tabular}{|c|c|c|c|c|}
\hline \multicolumn{5}{|c|}{$A R(a, b)_{i t}=\beta_{0}+\beta_{1} . D Y_{i t}+\varepsilon_{i t}$} \\
\hline & \multicolumn{2}{|c|}{$\begin{array}{l}\text { İmalat Sanayi } \\
\text { (859 gözlem) }\end{array}$} & \multicolumn{2}{|c|}{$\begin{array}{c}\text { Finansal Sektör } \\
\text { (587 gözlem) }\end{array}$} \\
\hline Olay Pencereleri & $\begin{array}{c}\text { RegresyonKatsayısı } \\
\left(\beta_{1}\right)\end{array}$ & $\mathrm{t}$ istatistiği & $\begin{array}{c}\text { RegresyonKatsayısı } \\
\left(\beta_{1}\right)\end{array}$ & $\mathrm{t}$ istatistiğ $\mathrm{i}$ \\
\hline$(-1,-1)$ & $0.05 *$ & 1.73 & 0.00 & 0.02 \\
\hline$(0,0)$ & $0.25 * * *$ & 5.90 & $0.19 * * *$ & 4.45 \\
\hline$(1,1)$ & $0.10 * * *$ & 3.16 & $0.08 * *$ & 2.02 \\
\hline$(-1,1)$ & $0.39 * * *$ & 7.20 & $0.28 * * *$ & 3.94 \\
\hline
\end{tabular}

*** \%1, **\%5, *\%10 seviyesinde anlamlılığı ifade etmektedir.

$\mathrm{AR}(\mathrm{a}, \mathrm{b})_{\mathrm{it}}=\mathrm{i}$ şirketinin t yllındaki temettü duyuru gününe göre $\mathrm{a}$ ve $\mathrm{b}$ günleri arasındaki normalüstü getirisi (Denklem 3 ).

$\mathrm{DY}_{\text {it }}=\mathrm{i}$ şirketinin t yllında duyurulan temettü verimi (Denklem 6).

Panelde zaman etkisi gözlenmemiş birim etkisinin varlığı tespit edilmiştir. Bu sebeple tek yönlü (birim etkili) panel regresyon modeline karar verilmiştir. Hem önsel bilgiler hem de Hausman testi sonucunda tek yönlü sabit etkiler modeli tercih edilmiştir. Otokorelasyon ve yatay kesit bağımlılığına rastlanmamış ancak değişen varyans problemine rastlanmıştır. Bu nedenle nihai olarak tek yönlü (birim etkili) sabit etkiler modelinde değişen varyans problemine karşı dirençli olan White (1980) tahmincisi kullanılmıştır. Ayrıca 1. nesil birim kök testleri (Levin, Lin ve Chu (1992) ve Hadri (2000) testleri) ile bağımlı ve bağımsız değişkenindurağanlığı kontrol edilmiș ve birim köke rastlanmamıștır. Yapılan testlere ait sonuçlar makalenin sayfa sayısını artırmamak amacıyla verilmemiş olup, hakem veya okuyucuların talep etmesi halinde paylaşılabilir.

Elde edilen tüm test sonuçları (kategorik analiz ve panel regresyon) hisse senedi fiyatlarının temettü duyurularına pozitif tepki gösterdiği yönündedir. Bu pozitif tepki temettü değişimi veya temettü verimi ile normalüstü getiriler arasında aynı yönlü ilişki olduğunu ifade etmektedir. Ayrica imalat sanayi şirketlerinde finansal şirketlere göre daha güçlü sonuçlar elde edilmiştir. Finansal şirketlerde temettü artışları veya yüksek temettü verimi içeren duyuruları pozitif fiyat etkisi yaratmış ancak temettü azalış veya düşük temettü verimi anlamlı seviyede negatif etki yaratmamıştır.

Ayrıca bulgular temettü veriminin yalın temettü değişimine göre hisse senedi fiyat tepkilerini daha iyi açıkladığına dair izlenim vermektedir. Bunu araştırmak için değişkenler arasındaki ilişkinin gücüne ilişkin standart bir ölçek sunan korelasyon analizi yapılmıştır. Bu sebeple hem temettü verimi hem de temettü değişiminin $(-1,1)$ olay penceresindeki normalüstü getiri ile olankorelasyon katsayıları Tablo 8 'da gösterilmiştir. ${ }^{23}$

Tablo 8. Korelasyon Analizi (İmalat Sanayi ve Finansal Şirketler İçin)

\begin{tabular}{|c|c|c|c|}
\hline Toplam Gözlem:1.426 & $\mathrm{AR}(-1,1)$ & $\mathrm{DY}$ & $\Delta$ Div \\
\hline AR(-1,1) & 1 & & \\
\hline DY & 0,30 & 1 & \\
\hline$\Delta$ Div & 0,13 & 0,37 & 1 \\
\hline
\end{tabular}

Tablo 8'den görülmektedir ki; normalüstü getrinin temettü verimi ile olan ilişkisi ( $\rho=0,30$ korelasyon) temettü değişimi ile olan ilişkisine göre $(\rho=0,13$ korelasyon) daha yüksektir. Yani hisse senedi fiyat tepkisi temettü değişimine kıyasla temettü verimine daha

\footnotetext{
${ }^{23}$ Tablo 8'deki korelasyon katsayıları, değişkenlerin birim ve zaman boyutları ihmal edilerek bütün gözlemler için yapılmıştır. Nitekim her bir birimdeki gözlem sayısının az olması nedeniyle bu yöntem tercih edilmiștir.
} 
yüksek olmaktadır. $\mathrm{Bu}$ tablo imalat sanayi ve finansal sektör şirketleri için ayrı ayr1 yapılmamış sonuçların birbirine yakın olması sebebiyle birlikte analizde dahil edilmiştir. $\mathrm{Bu}$ bulgu temettünün fiyat etkisini açıklamada yalın temettü değişimi yerine beklenen temettünün tahmini ile beklenmeyen temettü değişiminin hesaplamaların kullanılması gerekliliğine işaret etmektedir.

\subsection{Sağlamlık (Robustness) Testleri}

$\mathrm{Bu}$ kısımda ilk olarak temettü duyurularına hisse senedi fiyat tepkisinin şirket büyüklüklerine göre farklılaşıp farklılaşmadığı araştırılmıştır. Bunun için temettü duyuruları duyuruyu yapan şirketin öz kaynaklarının defter değerine göre ortanca gözlemden 2 gruba ayrılmıştır. Bu işlem imalat sanayi ve finansal sektör şirketleri için ayrı ayrı yapılmıştır. Örneğin imalat sanayi sektöründe yapılan 859 duyurunun 430'u küçük 429'u büyük şirket grubuna dahil edilmiştir. ${ }^{24}$ Daha sonra $\mathrm{H}_{1 \mathrm{a}}$ ve $\mathrm{H}_{2 \mathrm{a}}$ araştırma hipotezleri küçük ve büyük şirket duyuruları için ayrı ayrı panel regresyon yöntemi ile test edilmiştir.

Tablo 9'da imalat sanayi sektörüne ait sonuçlar bulunmaktadır. $\mathrm{H}_{1 a}$ hipotezinin testinde (bağımsız değiş̧ken temettü değişimi iken) büyük şirket duyurularında regresyon katsayısı ve $t$ istatistiği daha büyüktür. $\mathrm{H}_{2 \mathrm{a}}$ hipotezi için de (bağımsız değiş̧en temettü verimi iken) aynı durum geçerlidir. Bu sonuçlar imalat sanayi sektöründe büyük şirketlere ait temettü duyurularının fiyat etkisinin küçük şirketlere göre daha güçlü olduğunu göstermektedir.

Tablo 9. Şirket Büyüklüklerine Göre Temettü Duyurularının Etkisi

(İmalat Sanayi Sektörü)

\begin{tabular}{|c|c|c|c|c|}
\hline & \multicolumn{2}{|c|}{$\operatorname{AR}(-1,1)_{i t}=\beta_{\varepsilon_{i t}}^{\beta_{0}+} \beta_{1 . \Delta D i v_{i t}}+$} & \multicolumn{2}{|c|}{$\operatorname{AR}(\mathbf{a}, \mathbf{b})_{\text {it }}=\beta_{\varepsilon_{i t}}^{\beta_{0}+} \beta_{1 . D Y} . D Y_{i t}+$} \\
\hline & $\begin{array}{c}\text { Regresyon } \\
\text { Katsayı1 }\left(\beta_{1}\right)\end{array}$ & $\mathrm{t}$ istatistiği & $\begin{array}{c}\text { Regresyon } \\
\text { Katsayis1 }\left(\beta_{1}\right)\end{array}$ & $\mathrm{t}$ istatistiği \\
\hline $\begin{array}{c}\text { Küçük Şirket Duyuruları } \\
\text { (430 gözlem) }\end{array}$ & $0.09 * * *$ & 2.64 & $0.35 * * *$ & 4.49 \\
\hline $\begin{array}{l}\text { Büyük Şirket Duyuruları } \\
\text { (429 gözlem) }\end{array}$ & $0.14 * * *$ & 2.93 & $0.46 * * *$ & 5.33 \\
\hline
\end{tabular}

***: \%1 seviyesinde anlamlılı̆̆ göstermektedir.

Yapılan testler sonucunda tek yönlü (birim etkili) sabit etkili model kullanılmasına karar verilmiştir. Otokorelasyon ve yatay kesit bağımlılığına rastlanmamış ancak değişen varyans problemine rastlanmıştır. Bu nedenle sabit etkiler modelinde değişen varyans problemine karşı dirençli olan White (1980) tahmincisi kullanılmıştır.

Tablo 10 'da ise finansal sektöre ait sonuçlar bulunmaktadır. $\mathrm{H}_{1 \mathrm{a}}$ ve $\mathrm{H}_{2 \mathrm{a}}$ hipotezleri için büyük şirket duyurularında regresyon katsayıları ve $\mathrm{t}$ istatistikleri daha büyük olarak

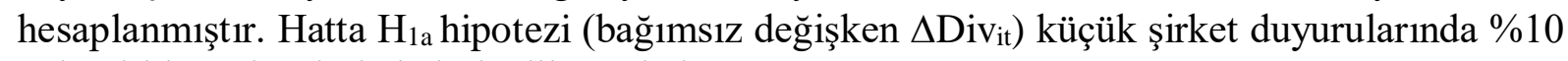
anlamlılık seviyesinde kabul edilmemiştir.

\footnotetext{
${ }^{24}$ Bir şirketin herhangi bir yıldaki duyurusu küçük şirket duyurusuna girerken aynı şirketin yıllar içindeki öz kaynakların defter değerindeki dramatik değişimden dolayı başka bir yıl yaptığı duyuru büyük şirket duyursuna girebilmekte veya bunun tam tersi olabilmektedir.
} 
Tablo 10. Şirket Büyüklüklerine Göre Temettü Duyurularının Etkisi (Finansal Sektör)

\begin{tabular}{|c|c|c|c|c|}
\hline & \multicolumn{2}{|c|}{$A R(-1,1)_{\text {it }}=\beta_{0}+\beta_{1} \cdot \Delta D_{i V_{i t}}+\varepsilon_{\text {it }}$} & \multicolumn{2}{|c|}{$A R(-1,1)_{i t}=\beta_{0}+\beta_{1} . D Y_{i t}+\varepsilon_{\text {it }}$} \\
\hline & $\begin{array}{c}\text { Regresyon } \\
\text { Katsayısı }\left(\beta_{1}\right)\end{array}$ & $\mathrm{t}$ istatistiğ $i$ & $\begin{array}{c}\text { Regresyon } \\
\text { Katsay1s1 }\left(\beta_{1}\right)\end{array}$ & $\mathrm{t}$ istatistiği \\
\hline $\begin{array}{l}\text { Küçük Şirket Duyuruları (284 } \\
\text { gözlem) }\end{array}$ & 0.07 & 1.21 & $0.28 * * *$ & 3.07 \\
\hline $\begin{array}{c}\text { Büyük Şirket Duyuruları (283 } \\
\text { gözlem) }\end{array}$ & $0.32 * * *$ & 3.71 & $0.30 * * *$ & 3.55 \\
\hline
\end{tabular}

***: \%1 seviyesinde anlamlilik

Yapılan testler sonucunda tek yönlü (birim etkili) sabit etkili model kullanılmasına karar verilmiştir. Otokorelasyon ve yatay kesit bağımlılığına rastlanmamış ancak değişen varyans problemine rastlanmıştır. Bu nedenle sabit etkiler modelinde değişen varyans problemine karşı dirençli olan White (1980) tahmincisi kullanılmıştır.

Elde edilen bulgular hem imalat sanayi hem de finansal sektörde temettü duyurularının büyük şirketlerde küçük şirketlere göre daha güçlü fiyat etkisi yarattığını göstermektedir (temettü artışlarında daha yüksek pozitif, temettü azalışlarında daha yüksek negatif normalüstü getiri). Bu bulgu literatürdeki teorik bilgiden farklıdır. Çünkü literatürde kurumsal yönetim ilkelerinin daha az uygulanması nedeniyle küçük şirketlerde yönetici ve yatırımcıları arasındaki bilgi asimetrisinin daha yüksek olduğu ve bu nedenletemettünün fiyat etkisinin daha yüksek olduğu savunulmaktadır(Buzby, 1975; Haw ve Kim, 1991). Ancak bu çalışmada elde edilen farklılı̆̆ın nedeni küçük şirketlerde sahiplik yoğunlaşmasının ${ }^{25}$ daha düşük olması olabilir. Çünkü sahiplik yoğunlaşması daha düşük olan şirketlerde temettünün yatırımcılara aktardığ 1 bilgi ve fiyat etkisi azalmaktadır (Özvar ve Ersoy, 2017:133).

Tablo 11. Alt Sektörlere Göre Temettü Duyurularının Fiyat Etkisi

\begin{tabular}{|c|c|c|c|c|}
\hline & & \multicolumn{3}{|c|}{$\operatorname{AR}(-1,1)_{i t}=\beta_{0}+\beta_{1} \cdot D Y_{i t}+\varepsilon_{i t}$} \\
\hline Sektör & Alt sektör & Gözlem Sayısı & $\begin{array}{c}\text { Regresyon Katsayıs1 } \\
\left(\beta_{1}\right)\end{array}$ & $\begin{array}{l}\text { Anlamlılık } \\
\text { Seviyesi (p) }\end{array}$ \\
\hline \multirow{7}{*}{$\begin{array}{l}\text { İmalat } \\
\text { Sanayi }\end{array}$} & Gıda İçki Tütün & 88 & 1.29 & 0.00 \\
\hline & Dokuma Giyim Deri & 59 & 0.43 & 0.00 \\
\hline & Kağıt Ürünleri Basım Yayın & 51 & 0.52 & 0.03 \\
\hline & Kimya Petrol Plastik & 155 & 0.20 & 0.07 \\
\hline & Taş ve Toprağa Dayalı İmalat & 239 & 0.49 & 0.00 \\
\hline & Metal Ana & 99 & 0.22 & 0.03 \\
\hline & Metal Eşya & 151 & 0.37 & 0.01 \\
\hline \multirow{7}{*}{ Finansal } & Banka ve Finans Kurumları & 96 & 0.14 & 0.32 \\
\hline & Sigortacılık & 44 & 0.46 & 0.03 \\
\hline & Leasing ve Faktoring & 21 & 0.33 & 0.26 \\
\hline & Holding ve Yatırım Şirketleri & 192 & 0.17 & 0.21 \\
\hline & Aracı Kurumlar & 24 & 0.10 & 0.44 \\
\hline & GYO & 111 & 0.51 & 0.00 \\
\hline & MKYO & 60 & 0.20 & 0.18 \\
\hline
\end{tabular}

Panel regresyon denklemi bütün testler yapıldıktan sonra birime göre tek yönlü sabit etkiler modeli ile tahmin edilmiştir. Bunun için değişen varyans sorununa dirençli White (1980) tahmincisi kullanılmıştır.

${ }^{25}$ Sahiplik yoğunlaşması şirketin öz kaynaklarına az sayıda kişi veya kurumun sahip olması yani mülkiyet hakkının birkaç kişi veya kurumda olmasıdır (Ersoy ve Çetenak, 2015: 509). 
Ayrıca bu kısımda hem finansal hem de imalat sanayi sektörü için elde edilen sonuçların alt sektörler bazında geçerli olup olmadığ 1 kontrol edilmiştir. Bunun için fiyat etkisini temettü verimi daha iyi açıkladığ 1 için $\mathrm{H}_{2 \mathrm{a}}$ hipotezi kullanılmıştır. Söz konusu hipotez alt sektörler bazında panel regresyon yöntemi ile test edilmiştir. Gözlem sayısı 20'nin altında olan alt sektörler için katsayılar hesaplanmamıştır. Tablo 11'de test sonuçları yer almaktadır. Görüldüğü gibi imalat sanayi ve finansal sektörün tüm alt sektörlerinde katsayılar pozitif ve anlamlıdır. Ancak gözlem sayısının yetersiz olmasından dolayı finansal sektöre ait bazı alt sektörlerde pozitif katsayılar anlamlı bulunmamıştır. Sonuç olarak imalat sanayiinde tüm alt sektörlerde finansal sektörde ise Sigortacılık ve GYO sektörlerinde temettü duyurusunun fiyat etkisiningeçerli olduğunu görülmüştür. Gözlem sayısının artması ile diğer alt sektörlerde de anlamlı pozitif katsayılar elde edilmesi muhtemel görünmektedir.

\section{SONUÇ}

Olay etüdü yöntemiyle temettü duyurusunu çevreleyen 3 günlük olay penceresinde hisse senetlerinin nakit temettü duyurularına pozitif fiyat tepkisi verdiği tespit edilmiştir. İmalat sanayi sektöründe dramatik temettü artışlarında pozitif, dramatik veya 1 lımlı temettü azalışlarında negatif normalüstü getiriler gözlenirken finansal sektörde sadece dramatik temettü artışlarına pozitif normalüstü getiri ölçülmüştür. Benzer şekilde imalat sanayi sektöründe yüksek temettü verimi içeren duyurularda pozitif düşük temettü verimi içeren duyurularda negatif normalüstü getiriler ölçülürken finansal sektörde yalnızca yüksek temettü verimi içeren duyurularda pozitif normalüstü getiriler görülmüştür. Her iki sektör için de temettü verimine göre ayrılan 2 grubun normalüstü getiri ortalaması arasındaki fark anlamlı bulunmuştur.

Ayrıca olay penceresindeki normalüstü getirilerle temettü değişimi/temettü verimi arasında panel regresyon analizi sonucunda söz konusu değişkenler arasında pozitif yönlü doğrusal ilişki belirlenmiştir. Regresyon katsayısı ve $t$ istatistikleri imalat sanayi sektöründe finansal sektöre göre daha yüksek çıkmıştır.

Elde edilen bulgular her iki sektör için temettünün pozitif fiyat etkisini destekler niteliktedir. Ancak analizlerde normalüstü getiriyi açıklamada temettü veriminin yalın temettü değişimine göre daha başarılı olduğu anlaşılmaktadır. Bununla birlikte yalın temettü yaklaşımından farklı metotların temettü değişimi değişkeni için kullanılmasını işaret etmektedir.

Sağlamlık (robustness) testi kısmında şirket büyüklüklerine göre temettü duyurularının fiyat etkisi araştırılmıştır. Büyük şirketlerde fiyat etkisinin daha yüksek ve daha anlamlı olduğu görülmüştür. Bu sonuç hem imalat sanayi hem de finansal sektör için geçerlidir. Elde edilen bu sonuç küçük şirketlerde büyük şirketlere göre sahiplik yoğunlaşmasınındaha yüksek olabileceği ihtimaline dayandırılmıştır.

Son olarak sağlamlık testi kısmında hem imalat sanayi hem finansal sektörler alt sektörlerine göre incelenmiştir. Temettü verimi ile normalüstü getiriler arasında yapılan panel regresyon tahmini sonucunda bütün alt sektörlerde pozitif regresyon katsayısı elde edilmiştir. Ancak finansal sektördegözlem sayısının sınırlı oluşundan dolayıbazı alt sektörlerde regresyon katsayılarının t istatistikleri anlamlı bulunmamıştır. 
Bundan sonra yapılacak çalışmalarda, yöneticilerle yatırımcılar arasında bilgi asimetrisinin ölçüsü olabilecek kurumsal yönetim endeksi, şirketi takip eden analist sayısı, ortaklık yoğunlaşması gibi kriterlere göre temettü duyuru etkisinin farklılaşıp farklılaşmadığı araştırmak bu alanda sınırlı sayıda çalışma yapılmış olan literatüre katkı sağlayacaktır.

\section{KAYNAKLAR}

Aamir, Muhammad - Shah, Syed Zullfiqar Ali (2011), "Dividend Announcements and the Abnormal Stock Returns for the Event Firm and its Rivals", Australian Journal of Business and Management Research, 1(8):pp. 72-76.

Aharony, Joseph - Dotan, Amihud (1994), "Regular Dividend Announcements and Future Unexpected Earnings: An Empirical Analysis", Financial Review, 29(1):pp. 125-151.

Akhigbe, Aigbe-Madura,Jeff (1996), "Dividend Policy and Corporate Performance", Journal of Business Finance and Accounting, 23(9): pp. 1267-1287.

Ali, Ijaz - Muhammad, Noor-Gohar, Ali(2017), "Do FirmsUse Dividend Changes to Signal Future Earnings? An Investigaation Based on Market Rationality", International Journal of Economicsand Finance, 9(4): pp. 20-34.

Arslan, Özgür (2008), "Firma Yöneticilerinin Temettü Dă̆ıtımlarına Dair Algıları", Hacettepe Üniversitesi İktisadi ve İdari Bilimler Fakültesi Dergisi, Cilt 26, 1: pp. 8599.

Asquith, Paul - Mullins, David W. (1983), "The Impact of Initiating Dividend Payments on Shareholders' Wealth", TheJournal of Business, 56(1): pp. 77-96.

Bajaj, Mukesh - Vijh, AnandM.Vijh (1990), "Dividend Clienteles and the Information Content of Dividend Changes", Journal of Financial Economics, 26: pp. 193-219.

Başkaya, Hatice (2015),“Halka Açık Firmalarda Kâr Payı Dağııım Duyurularının Hisse Senedi Fiyatlarına Etkisinin Olay Etüdü ile Ölçülmesi”, Yüksek Lisans Tezi, Adnan Menderes Üniversitesi, Sosyal Bilimler Enstitüsü, Aydın.

Black, Fisher (1976), “The Dividend Puzzle", Journal of Portfolio Management, Special Issue:pp. 8-12.

Berezinets,Irina - Ilina,Yulia - Smirnov,Marat- Bulatova, Liliia (2017), "How Does Stock Market Reactto Dividend Surprises? EvidencefromEmergingMarkets of IndiaandRussia", Journal of Asia-Pacific Business, 18(3): pp. 153-179.

Cebenoyan, A.Sinan. - Strahan, Philip E.(2004), "Risk Management, Capital Structure and Lending at Banks", Journal of Banking\& Finance, 28: pp. 19-43.

Denis, David J. - Denis, DianeK.- Sarin,Atulya (1994), "The Information Content of Dividend Changes: Cash Flow Signaling, Overinvestment, and Dividend Clienteles", Journal of Financial and Quantitative Analysis, 29(4): pp. 567-587. 
Ersoy, Ersan - Çetenak, Emin (2015), “Sahiplik Yoğunlaşmasının Temettü Dağıtım Kararlarına Etkisi: Borsa İstanbul'da Bir Uygulama”, Ege Akademik Bakış, Cilt:15, 4: ss. 509-521.

Günalp, Burak - Kadığlu, Eyüp - Kılıç, Saim (2010), "Nakit Temettü Bilgisinin Hisse Senedi Getirisi Üzerinde Önemli Bir Etkisinin Olup Olmadığının İMKB'de Test Edilmesi”, H.Ü. İktisadi ve İdari Bilimler Fakültesi Dergisi, Cilt 28, 2: ss. 47-69.

Güriş, Selahattin (2015), Stata ile Panel Veri Modelleri, İstanbul: Der Yayınları.

Gunasekarage, Abeyratna - Power, David M. (2006), "AnomalousEvidence in Dividend AnnouncementEffect”, Managerial Finance, 32(3): pp. 209-226.

Haw, InMu - Kim, Wi Saeng(1991), “Firm Size and Dividend AnnouncementEffect”, Journal of Accounting, Auditing \& Finance, 6(3):pp. 325-344.

Healy, Paul M. - Palepu,Krishna.G (1987), "Earnings Information Conveyedby Dividend Initiations and Omissions", Working Paper, Massachusetts Institute of Technology, Alfred P. Sloan of Management.

Hernandez, Martin Diego Berg (2017), "How Does the Norwegian Stock Market React to Unexpected Dividend Announcements?", Master Thesis, BI Norwegian Business School, Oslo.

Kadığlu, Eyüp (2008), "TheAnnouncement Effect of Cash Dividend: Evidence from Turkish Capital Market”, Master Thesis, Leeds University Business School, Leeds.

Kadığlu, Eyüp -Telçeken, Niyazi- Öcal, Nurcan(2015),"Market Reactionto Dividend Announcement: Evidence from Turkish Stock Market", International Business Research; 8(9):pp. 83-94.

Kaymaz, Özgür (2010), "Şirket Temettü Politikasında Sinyalizasyon Teorisi ve Bir İmkb Uygulaması, Doktora Tezi, İstanbul Üniversitesi, Sosyal Bilimler Enstitüsü,İstanbul.

Kırbaş, Ayhan (2015), “Temettü Duyurularının Hisse Senedi Getirilerine Olan Etkilerinin Analizi: Borsa İstanbul Şirketlerinde Bir Uygulama”, Doktora Tezi, Başkent Üniversitesi, Sosyal Bilimler Enstitüsü, Ankara.

Michaely,Roni - Thaler, Richard H. - Womack, Kent L. (1995), "Price Reactions to Dividend Initiations and Omissions: Overreactionor Drift?", The Journal of Finance, L(2):pp. 573-608.

Nissim, Doron - Ziv,Amir (2001), "Dividend Changes and Future Profitability”, TheJournal of Finance, LVI (6): pp. 2111-2134.

Özvar, Koray- Ersoy, Ersan(2017),“Sahiplik Yapısının Kâr Dağıtım Kararlarına Etkisi: Panel Tobit Yöntemiyle Bir Analiz”, Finansal Araştırmalar ve Çalışmalar Dergisi, Cilt: 9, 17:pp. 129-147. 
Qudah, AnasA.L. - Badavi,Ahmed (2014), "The Signaling Effects and Predictive Powers of Dividend Announcements: Evidence from Kingdom of Saudi Arabia", Proceedings of the First Asia-Pacific Conference on Global Business, Economics, Finance andSocialSciences, Singapore,pp. 1-3.

Sakarya, Şakir - Çalış, Nevzat- Kayacan, Mehmet Arif (2018), “Temettü Ödeme Duyurularının Hisse Senedi Fiyatlarına Etkisinin Ölçülmesi: Borsa İstanbul' da Bir Uygulama”, Sakarya İktisat Dergisi, Cilt 7, 2:pp. 92-106.

Suwanna, Thanwarat(2012), "Impacts of Dividend Announcement on Stock Return", Procedia - Socialand Behavioral Sciences, 40:pp. 721-725.

Vieira, ElisabeteSimões(2005), "Signalling with dividends? The Signalling Effects of Dividend Change Announcements: New Evidencefrom Europe", Phd Thesis, Universidade de Aveiro Management Department Rua Associação H. B. Voluntários, Portugal.

Y1lmaz, Ayşe Altık- Selçuk, Elif Akben(2010), "Information Content of Dividends: Evidence from Istanbul Stock Exchange”, International Business Research, 3(3):pp. 126-132. 